PAedagogia Christiana

I/29 (2012) - ISSN 1505-6872

Teresa Hejnicka-Bezwińska*

Bydgoszcz

\title{
Ideologiczne uwikłanie celów formułowanych w obszarze edukacji
}

\section{Wprowadzenie}

Wypowiedź na temat ideologicznego uwarunkowania celów formułowanych (werbalizowanych - realizowanych) w obszarze edukacji - zgodnie z przesłanym mi zaproszeniem Redaktora niniejszego tomu - ma być usytuowana w pracy zbiorowej poświęconej Antynomiom wspótczesnej edukacji i pedagogiki. Wola wpisania się w zamysł redakcyjny zadecydowała o zakresie i strukturze treści włączonych do niniejszego artykułu. Możliwość jednak przyjęcia różnych perspektyw poznawczych w opisie, wyjaśnianiu i interpretacji problemu ideologicznego uwikłania celów formułowanych w obszarze edukacji skłania mnie do wskazania tej, którą w danym tekście przyjmuję.

Moje doświadczenie związane z przygotowaniem pracy zbiorowej zatytułowanej Problemy, antynomie, dylematy i kontrowersje $w$ myśleniu o pedagogice i edukacji ${ }^{1}$, podsumowującej dziesięcioletni dorobek Zespołu Pedagogiki Ogólnej i Porównawczej przy Komitecie Nauk Pedagogicznych PAN - pozwala mi na stwierdzenie, że problematyzowanie oraz podejmo-

* Prof. zw. dr hab. Teresa Hejnicka-Bezwińska - kierownik Katedry Pedagogiki Ogólnej i Porównawczej na Wydziale Pedagogiki i Psychologii Uniwersytetu Kazimierza Wielkiego w Bydgoszczy.

1 T. Hejnicka-Bezwińska, Problemy, antynomie, dylematy $i$ kontrowersje w myśleniu o pedagogice i edukacji, Bydgoszcz 2003. 
wanie prób „porządkowania” dyskursów o społecznej praktyce edukacyjnej jest ważnym zadaniem współczesnej pedagogiki jako dyscypliny naukowej, a szczególnie tego jej obszaru, który nazywa się „,pedagogiką ogólną””. Nie będąc zwolenniczką akcentowania „murów” oddzielających poszczególne dyscypliny naukowe, ani zwolenniczką zawłaszczania problemów przez poszczególne dyscypliny i subdyscypliny naukowe, chcę powiedzieć, że moja deklaracja o przyjęciu perspektywy poznawczej współczesnej pedagogiki ogólnej oznacza jedynie tyle, że mój namysł nad ideologicznym uwikłaniem celów edukacji wykorzystywać będzie najbardziej ogólny poziom myślenia pedagogicznego i wiedzę o nauce i edukacji, która została wytworzona przez różne dyscypliny naukowe. Usprawiedliwieniem dla stosowania najwyższego poziomu ogólności jest przekonanie, że sprzyja ono problematyzowaniu, a zatem zakłada autorskie wpisywanie się w budowanie nowych związków nauki z praktyką (najważniejszy atrybut współczesnej humanistyki), który zdaniem psychologów - dobrze służy podwyższaniu poziomu „responsywności”’3 jako odpowiedzi na utopijny optymizm świata nowoczesnego związany z nauką zredukowaną do orientacji pozytywistycznej, o którym Slawoj Żiżek tak powiedział: „Prawdziwa utopia to wiara, że mamy ostateczną formułę, dzięki której świat będzie coraz lepszy, że problem fundamentalny został rozwiązany i do załatwienia mamy tylko różne kwestie praktyczne"4.

Najprościej natomiast kłopoty związane $\mathrm{z}$ wykorzystaniem nauki w praktyce wyraził - w moim przekonaniu - Leszek Kołakowski, mówiąc:

[...] umysł nasz chce rozumieć i wiedzieć, co to jest prawda i jak ją rozpoznać; chce wiedzieć, co to jest zło czy dobro albo sprawiedliwość, albo przyczyna, albo czy świadomość jest zjawiskiem fizycznym, albo czy zachodzi pewność i na czym ona polega, albo czy język nasz świat jakoś odzwierciedla, czy raczej go tworzy, albo dlaczego należy być porządnym człowiekiem. Na niektóre z tych pytań wprawdzie odpowiadają czasem fizycy, biologowie czy

${ }^{2} \mathrm{Z}$ uwagi na rozbieżności w pojmowaniu pedagogiki oraz poszczególnych jej subdyscyplin czuję się zobowiązana do zadeklarowania, że pojmuję ją tak, jak przedstawiłam to w podręczniku: T. Hejnicka-Bezwińska, Pedagogika ogólna, Warszawa 2008.

${ }^{3}$ Responsywne myślenie o edukacji (w tym także i o oświacie) zakłada taki poziom ogólności, aby możliwe było problematyzowanie właściwe współczesnej humanistyce, które jest warunkiem uruchomienia społecznego dyskursu o edukacji różnych podmiotów zaangażowanych w tworzenie społecznej praktyki edukacyjnej, które w różnym stopniu mogą korzystać z wiedzy pedagogicznej, jak również różny może być ich poziom przygotowania do korzystania $z$ wiedzy naukowej.

${ }^{4}$ Są to słowa z wywiadu przeprowadzonego z prof. Slawojem Żiżkiem, zamieszczone w książce: J. Żakowski, Rozmowy o tym, co się popsuło u nas, $w$ Polsce, w Europie, w świecie, Warszawa 2006, s. 72-73. 
psychologowie, ale nie odpowiadają naprawdę z pozycji swoich scjentystycznych umiejętności, lecz raczej swój scjentystyczny autorytet wykorzystują dla filozoficznych celów; to jest dopuszczalne, lecz „fizyka” ani „biologia” nie dają takich odpowiedzis.

Wielka zmiana kulturowa związana z przechodzeniem od świata nowoczesnego do świata ponowoczesnego ujawnia się w zjawisku kryzysu obejmującym wszystkie dziedziny kultury, w tym także edukację i naukę. W polskiej pedagogice uruchomiony został proces jego przezwyciężania, ale opis, wyjaśnianie i interpretacja zmian są bardzo zróżnicowane. Okazją do zapoczątkowania procesu przezwyciężania kryzysu był I Ogólnopolski Zjazd Pedagogiczny (1993), którego uczestnicy obradowali na temat ewolucji tożsamości pedagogiki. Nadal jednak kontrowersyjna wydaje się kwestia dominacji orientacji pozytywistycznej - dokładniej dominacji pedagogiki empirycznej, w której znajdowało uzasadnienie poszukiwanie uniwersalnych ,doktryn pedagogicznych"6. I nie jest przeszkodą w tym nasze szczególne doświadczenie historyczne związane z dominacją tak zwanej ,naukowej pedagogiki socjalistycznej". Uchylenie tej dominacji w procesie transformacji ustrojowej zapoczątkowało jednak proces przejścia w pedagogice od ortodoksji ku hetoregeniczności ${ }^{7}$. Nie jest to proces zakończony, jeżeli mierzyć go będziemy stopniem konwencjalizacji ${ }^{8} \mathrm{w}$ praktyce edukacyjnej, $\mathrm{w}$ tym także w praktyce kształcenia w zakresie pedagogiki na poziomie akademickim.

To przejście spowodowało zasadnicze zmiany dotyczące pedagogiki jako dyscypliny naukowej, a więc zmiany w przedmiocie badań, uznawanej metodologii badań naukowych, statusie pedagogiki i jej związkach z prak-

5 L. Kołakowski, Moje wróżby w sprawie religii i filozofii, w: J. Kozielecki (red.), Humanistyka przełomu wieków, Warszawa 1999, s. 314.

${ }^{6}$ Współcześnie doktryną pedagogiczną nazywa się autorską koncepcję celowościowego procesu edukacyjnego (wychowania, kształcenia, nauczania, uczenia się), zawierającą: a) opis i uzasadnienie celów, b) opis systemu oddziaływań mających uzasadnienie w teoriach naukowych, c) dyrektywy praktycznego działania. Historię doktryn pedagogicznych odróżnia się od historii myśli pedagogicznej. S. Sztobryn doktryną pedagogiczną nazywa ,wszelkie usystematyzowane, teoretycznie uzasadnione i wyposażone w bogatą aparaturę pojęciową hipotezy i twierdzenia dotyczące wychowania człowieka, odniesione do składników rozumienia tego pojęcia" przyjętych w określonym miejscu i czasie historycznym (orientacji pedagogicznej, nurcie, kierunku, paradygmacie).

7 Proces ten opisałam w książce: T. Hejnicka-Bezwińska, Tożsamość pedagogiki. Od ortodoksji ku heterogeniczności, Warszawa 1997.

${ }^{8}$ Szerzej na ten temat piszę w: T. Hejnicka-Bezwińska, Rekonstrukcja logiki transgresji historycznej w obszarze edukacji, w: tenże (red.), Pedagogika ogólna. Dyskursy o statusie naukowym i dydaktycznym, Bydgoszcz 2011. 
tyką edukacyjną, koncepcji roli uczonego. Źródeł tej zmiany należy jednak poszukiwać nie tylko w transformacji ustrojowej, ale także w zmianie kulturowej, która dokonała się w koncepcji człowieka i świata oraz modelu nauki w świecie przechodzącym od świata nowoczesnego ku światu ponowoczesnemu, a jego wizja jest ciągle wielce sproblematyzowana, pełna kontrowersji, dylematów i antynomii. Ten problem - zgodnie z zapowiedzią redaktora naukowego niniejszego tomu - zostanie omówiony w innych artykułach i w tym tekście może być tylko zasygnalizowany. Nie czuję się jednak zwolniona od zdefiniowania i omówienia kluczowych kategorii pojęciowych ${ }^{9}$ zastosowanych w tytule artykułu.

\section{Zakres, treść i zastosowanie kluczowych kategorii pojęciowych}

W tytule pracy zostały zastosowane dwie kategorie pojęciowe wymagające omówienia: 1) ,ideologia”, 2) „edukacja”. Obydwie kategorie są kategoriami pojęciowymi wieloznacznymi, uwikłanymi w historyczny proces zmian zakresu i treści. $Z$ tego powodu aktualne ich zastosowanie wymaga nie tylko zdefiniowania tych kategorii pojęciowych, ale także zrekonstruowania kontekstu takiego ich rozumienia. Z drugiej strony rozumiem niechęć czytelnika do zabiegów definiowana, ale unikanie zakłóceń i deformacji poznawczych w procesie przekazu wiedzy jest dla mnie wartością ważniejszą niż niechęć uczestników procesu komunikacyjnego do czynności potocznie uważanych za stratę czasu. Nauka jednak wie, że potoczne poczucie wiedzy i rozumienia opartego na tak zwanych „oczywistościach” osiąga człowiek za cenę niskiego poziomu legitymizacji tego, co wie. Wiedza potoczna jest bowiem fragmentaryczna, niespójna, podatna na różnego typu deformacje poznawcze, pochopna, apodyktyczna itp.

9 Wielość orientacji współistniejących w pedagogice sprawia, że każda z nich posługuje się swoistą „mapą kategorialną”. Może być ona wykorzystana do konstruowania wiedzy o rzeczywistości edukacyjnej (w tym celu w podręcznikach akademickich pedagogiki jako ważna ich część - występują różnie konstruowane „słowniki”) a systemy kategorialne właściwe różnym nurtom pedagogicznego myślenia mogą być ważnym narzędziem ,dekonstruowania” (w znaczeniu nadanym tej kategorii pojęciowej przez Jacquesa Derridę) tego, co zostało wytworzone w wyniku „społecznego tworzenia rzeczywistości” (w znaczeniu nadanym tej kategorii pojęciowej przez Petera Bergera i Thomasa Luckmanna). Moje definicje kategorialne w niniejszym tekście będą odwoływały się do „Słownika kategorii pojęciowych” zamieszczonych w: T. Hejnicka-Bezwińska, Pedagogika ogólna, s. 457-518. 


\subsection{Zakres i treść oraz pierwotne zastosowania kategorii pojęciowej: „ideologia"}

W cytowanym już wcześniej podręczniku napisałam tak:

Ideologia: termin ,ideologia” (idéologie) został stworzony pod koniec XVIII wieku przez francuskiego filozofa Destutta de Tracy - autora Elements d idéologie i założyciela szkoły filozoficznej ,ideologów”. W pierwszej fazie „,ideologią" nazywano naukę o ideach. Później zastosowano tę kategorię pojęciową do nazywania pewnych kombinacji idei, ich syndromów i w związku z tym przedmiotem zainteresowania badaczy ideologii stał się społeczny i polityczny wymiar funkcjonowania idei i ideologii ${ }^{10}$.

W kontekście tak rozumianej i stosowanej kategorii pojęciowej ideologii moglibyśmy pytać: Jaka ideologia przyświecała zwolennikom dyscyplinaryzacji i instytucjonalizacji pedagogiki w strukturach akademickich na przełomie XVIII i XIX wieku?

Poszukując odpowiedzi na to pytanie, znajdujemy coraz więcej dowodów na to, że to właśnie nadzieje związane $\mathrm{z}$ tworzeniem systemu oświatowego oraz potrzeby praktyki oświatowej ujawnione na przełomie XVIII i XIX wieku stały się czynnikiem sprawczym zmian tworzących warunki do powstania pedagogiki jako dyscypliny naukowej, w ramach której unaukowione zostać miało tworzenie podstawowej instytucji systemu oświatowego (szkoły) oraz profesjonalizacja zawodu nauczyciela.

W Niemczech XIX wieku uważano reformę pruskiego systemu oświatowego za integralną część całościowej reformy państwa, obejmującej przebudowę systemu politycznego, reformy agrarne, reformę administracji państwowej i wojska, reformę w zakresie praw obywatelskich i inne. Ten szeroki zakres zmian miał być środkiem i narzędziem do zbudowania nowej tożsamości Niemców, umożliwiającej odbudowanie imperialnej potęgi Niemiec. Reforma oświaty dotyczyła wszystkich szczebli kształcenia. Najszybciej reforma została przeprowadzona na szczeblu akademickim, poprzez wdrożenie humboldtowskiego modelu uniwersytetu. Za szczególnie ważne osiągnięcie reformy oświatowej należy natomiast uznać wypracowanie koncepcji gimnazjum jako szkoły przygotowującej elity. Problem wzrostu autorytetu nauczyciela i szkoły jako warunku bardziej skutecznego wypełniania misji mógł być rozwiązany jedynie poprzez profesjonalizację zawodu na-

\footnotetext{
10 Tamże, s. 476.
} 
uczyciela. Zgodnie z oświeceniową ideą postępu i modelem nauki w świecie nowoczesnym zadanie to mogło być spełnione poprzez wpisanie tego zawodu w kształcenie akademickie, a mogło się to dokonać jedynie poprzez dyscyplinaryzację i instytucjonalizację pedagogiki.

Biorąc pod uwagę zasygnalizowany zakres zjawisk i procesów, możemy powiedzieć, że podporządkowanie rozwoju świata nowoczesnego oświeceniowej idei postępu, a szerzej ideologii świata nowoczesnego, stworzyło warunki dla upolitycznienia procesu dyscyplinaryzacji i instytucjonalizacji pedagogiki. Jako szczególny przypadek upolitycznienia dyscyplinaryzacji i instytucjonalizacji pedagogiki można potraktować także dzieje pedagogiki w PRL-u. Uniwersalna, a zatem niedyskursywna w pewnym okresie ideologia świata nowoczesnego sprawiła, że upolityczniony został proces dyscyplinaryzacji i instytucjonalizacji pedagogiki, natomiast jego wymiar ideologiczny stał się wymiarem ukrytym, ponieważ w pewnym okresie czasu historycznego nie podlegał problematyzacji, nie był dyskursywny.

Przyjmując pierwotne znaczenie polityki jako działań na rzecz określonej wspólnoty, możemy jedynie pytać w tym kontekście o wkład pedagogiki w budowanie tożsamości narodowej i państwowej w Europie (poszczególnych państwach Europy) lub też pytać o wkład pedagogiki w budowanie wspólnot kulturowych ${ }^{11}$, na przykład „kultury demokratycznej i rynkowej” lub „kultury 'realnego socjalizmu”. Obie kultury były obecne w Europie $\mathrm{XX}$ wieku. W tym kontekście pytanie o pedagogikę jest zawsze pytaniem o doktryny pedagogiczne i ich polityczny sens oraz polityczne wykorzystanie.

Mamy wiele przykładów, że proces awansu pedagogiki jako dyscypliny naukowej, a później proces ekspansji pedagogiki, był procesem trudnym. Długo depozytariusze kapitału przypisanego nauce dyskutowali o słabości pedagogiki w kontekście standardów nauk nie tylko przyrodniczych, ale także nauk humanistycznych. Przez ponad 150 lat powracało z uporem pytanie: Czy pedagogika nauką jest? Dopiero postmodernistyczna krytyka świata nowoczesnego i przezwyciężenie dominacji pozytywistycznego modelu uprawiania nauki sprawiło, że uchylony może być sens dalszego zadawania tego pytania. Możemy zatem powiedzieć, że wspólczesny kryzys pedagogiki polega na tym, że nie musi ona już udowadniać, że nauką jest, ale musi zaświadczyć o potrzebie swego istnienia tym, że przyczynia się do powstawania bardziej wiarygodnej wiedzy o swoim przedmiocie badań.

${ }^{11}$ Charakterystykę obydwu wymienionych wspólnot kulturowych przyjmuję za Piotrem Sztompka, Socjologia. Analiza społeczeństwa, Warszawa 2002. 
Ta zmiana powoduje, że kategoria ideologii znajduje inne zastosowanie we współczesnych badaniach pedagogicznych.

\subsection{Zmiana w stosowaniu kategorii ,ideologii” w pedagogice współczesnej}

W XX wieku termin ,ideologia” znalazł zastosowanie w języku filozofii, naukach społecznych, a także w mowie potocznej. Pod koniec XX wieku pojęciem ideologii zaczęli posługiwać się również pedagodzy. Pedagodzy różnią się jednak tym, że jedni posługują się tą kategorią pojęciową jako kategorią opisową, a inni wykorzystują ją jako kategorię wartościującą (stygmatyzującą i piętnującą). W obszarze polskiej potoczności $-\mathrm{z}$ powodów historycznie uzasadnionych - bardzo silnie zakorzenione jest stosowanie „ideologii” jako kategorii wartościującej w sensie negatywnym, dla naznaczenia, stygmatyzowania i napiętnowania. Nauka odwołuje się natomiast do tej kategorii pojęciowej jako kategorii opisowej. Akcentuję ów fakt, aby ograniczyć możliwe deformacje poznawcze związane z odczytaniem niniejszego tekstu.

Deklarując posługiwanie się kategorią ,ideologii” jako kategorią opisową, mogę przyjąć, że pojęciem tym

[...] będziemy nazywać zbiór (lub system) idei, które dostarczają uzasadnienia, legitymizacji, wsparcia pewnym interesom grupowym lub/i utwierdzają tożsamość określonej grupy społecznej. Jej elementami strukturalnymi są: 1) interpretacja przeszłości, która nadaje grupie określoną perspektywę czasową i przestrzenną - wyrażona w formie zdań orzekających (mogą one być wytworzone przez badania empiryczne), 2) opis i ocena obecnej sytuacji w obszarze, którego ta ideologia dotyczy (polityki, struktury i funkcjonowania społeczeństwa, gospodarki, oświaty i inne) - wiążąca opis z wartościowaniem (zdania wartościujące mogą mieć charakter filozoficzno-światopoglądowy lub odwoływać się do racji pragmatycznych), 3) koncepcje zmiany, w tym również strategie działania najbardziej pożądane i skuteczne wobec planowanej zmiany, wyrażone w postaci dyrektyw działania, czyli czynności, które należy podjąć i zrealizować ${ }^{12}$.

12 T. Hejnicka-Bezwińska, Pedagogika ogólna, s. 476-477. 
Przyjmując taką definicję ideologii, możemy mówić o ideologiach edukacyjnych, ideologiach wychowania, ideologiach kształcenia, ideologiach szkoły, ideologiach konstytuujących system oświatowy i inne.

Tytuł zapowiada, że mowa będzie o „ideologii edukacyjnej”, a zatem pozostaje jeszcze do zdefiniowania i omówienia jej zastosowania kategoria pojęciowa „edukacji”.

\subsection{Kategoria pojęciowa „edukacji” w strukturze pojęciowej współczesnej pedagogiki}

W pedagogice tradycyjnej, która swym przedmiotem badań czyniła celowościowe procesy występujące w instytucjach tworzących system oświatowy, trzy pojęcia mogły być stosowane zamiennie: edukacja - wychowanie - kształcenie. Proces rozwoju pedagogiki i ewolucji jej tożsamości spowodował, że każda z tych kategorii pojęciowych uzyskała właściwy dla siebie zakres i treść w polskiej pedagogice współczesnej oraz inne w związku z tym zastosowanie.

Odwołując się do podręcznikowej wersji „ogólnej struktury systemu pojęć pedagogicznych”"13, możemy uznać, że kategoria „edukacji” ma najszerszy zasięg znaczeniowy i z tego powodu jest kategorią najmniej jednorodną, a zatem stosowanie jej pozwala na najwyższy poziom ogólności. Elementami strukturalnymi definicji tak rozumianej „edukacji” są następujące określenia:

- jest to ogół oddziaływań (różnie klasyfikowanych),

- obejmujących wiele procesów (ich typologie są różne),

- pomiaru efektów tych procesów można dokonać, operacjonalizując najbardziej ogólnie pojmowaną kategorię ,zdolności życiowe człowieka”.

Kategorie pojęciowe ,wychowania” i ,kształcenia” mają już węższy zakres znaczeniowy, ale za to bogatszą treść i są w związku z tym kategoriami pojęciowym bardziej jednorodnymi. $Z$ uwagi na to, że jedna $\mathrm{z}$ tych kategorii nazywa przedmiot subdyscypliny naukowej nazwanej „teorią wychowania”, a druga nazywa przedmiot dydaktyki (teorii kształcenia), więc w tych subdyscyplinach naukowych są one bliżej definiowane.

Na jeszcze niższym poziomie (III) znajdują się kategorie związane z systemem oświatowym (oświatowo-wychowawczym). IV piętro (najniższe

${ }^{13}$ K. Rubacha, Edukacja jako przedmiot pedagogiki i jej subdyscyplin, w: Z. Kwieciński, B. Śliwerski (red.), Pedagogika. Podręcznik akademicki, Warszawa 2003, s. 27. 
w omawianym rysunku) jest zajęte przez pojęcia (mapy pojęciowe) stosowane w poszczególnych (szczegółowych) subdyscyplinach pedagogicznych.

Odwołując się do omawianego schematu możemy stwierdzić, że zastosowanie kategorii pojęciowej „edukacji” jest właściwe perspektywie poznawczej najbardziej ogólnej, a ta przypisana jest pedagogice ogólnej, jeżeli posłużymy się podręcznikową wersją struktury pedagogiki.

Ten wywód stanowi uzasadnienie dla decyzji, że w perspektywie poznawczej najbardziej ogólnej należy mówić o ideologicznym uwikłaniu celów edukacyjnych, a uwikłania celów wychowania i kształcenia oraz innych procesów edukacyjnych pozostawić reprezentantom pozostałych subdyscyplin pedagogicznych.

\section{2. „Ideologie edukacji (edukacyjne)”}

We współczesnej pedagogice ogólnej znajduje - w moim przekonaniu uzasadnienie następująca definicja rozpatrywanej w tej części kategorii pojęciowej $^{14}$ :

Ideologie edukacyjne: poglądy grup społecznych na temat edukacji, wyrażające ich interesy i dążenia edukacyjne. Wyodrębnione one mogą być według różnych kryteriów: 1) kryterium klasowego (arystokratyczna - burżuazyjna - proletariacka); 2) stosunku do zmiany społecznej (konserwatywne - progresywne); 3) orientacji teoretycznej (psychologiczne - socjologiczne - kulturowe); 4) roli jednostki i grupy społecznej (indywidualistyczne - kolektywistyczne); 4) podmiotu (pajdocentryczne - autorytarne); 5) stosunku do tzw. „szkoły tradycyjnej" (konserwatywne - liberalne); 6) stosunku do idei równości (elitarystyczne - egalitarne) i inne. Współcześnie ważnym przedmiotem badań są konkretne co do miejsca i czasu historycznego ,polityki oświatowe” realizowane przez poszczególne państwa. Ich efektem są rekonstrukcje ideologii edukacyjnych ${ }^{15}$.

Definicja ta wykorzystuje ustalenia dotyczące ,ideologii edukacyjnych”, zawarte w podręczniku napisanym przez Ronalda Meighana ${ }^{16}$ oraz ustale-

${ }^{14} \mathrm{~W}$ tej części czuję się zobowiązana uzasadnić moje uporczywe posługiwanie się określeniem „kategorie pojęciowe” (zamiast krótko „pojęcia”). Chcę przez to zaznaczyć, że sytuuję swoje rozważania w tej tradycji filozoficznej badań, w której znajduje uzasadnienie teoria dekonstrukcjonizmu J. Derridy.

15 T. Hejnicka, Pedagogika ogólna, s. 477.

16 R. Meighan z udziałem L. Bartona i S. Walkera, Socjologia edukacji, Toruń 1993. 
nia Geralda Gutka ${ }^{17}$ na ten temat. W oparciu o wiedzę dotyczącą ideologii, możemy powiedzieć, że każda ideologia edukacyjna skonstruowana jest z trzech rodzajów zdań:

1. Zdania orzekające o rzeczywistości edukacyjnej jako dziedzinie kultury określonego miejsca i czasu historycznego (zdania te mogą mieć status twierdzeń empirycznych albo wyrażać potoczną wiedzę jednostki lub grup społecznych).

2. Zdania wartościujące, odnoszące się do aktualnego stanu i efektów procesów edukacyjnych lub instytucji i osób za te procesy odpowiedzialnych. Punktem odniesienia są wartości o charakterze filozoficzno-światopoglądowym ${ }^{18}$.

3. Zdania mające charakter postulatów zmiany i dyrektyw praktycznego działania.

$\mathrm{W}$ ideologiach edukacyjnych cele edukacyjne pojawiają jako ten trzeci rodzaj zdań występujących w każdej ideologii. Nie są to jednak zdania formułowane przez naukę. Przypomnę, że w wielu swoich pracach o ewolucji tożsamości pedagogiki akcentowałam, że we współczesnej pedagogice żadne twierdzenia i teorie nie stanowią wystarczającego zbioru przesłanek, uzasadniających jakiekolwiek dzialania edukacyjne. Tym bardziej nie mogą uzasadniać narzucania działań, mających służyć realizacji określonych celów. Jeżeli jednak przesłankę opisującą (twierdzenie empiryczne) uzupełnimy przesłanką wartościującą (zdaniem normatywnym), to otrzymamy sylogizm, który spełnia kryteria schematu wnioskowania pośredniego.

Twierdzenia empiryczne są oczywiście uznawane za niekwestionowany wytwór nauki. Natomiast prawomocność przesłanki wartościującej zależy od tego, czy strony są skłonne zaakceptować określone wartości, kryteria oceny, a wreszcie opinie, przekonania i poglądy innych na określony temat czy w określonej sprawie. Jeżeli pedagogika normatywna nie da się w sposób uprawomocniony „wywieść” $\mathrm{z}$ faktów empirycznych, to jedynym sposobem jej uprawomocnienia są społeczne dyskursy edukacyjne. $Z$ wielu zna-

${ }^{17}$ G. L. Gutek, Filozoficzne i teologiczne podstawy edukacji, Gdańsk 2003.

18 „Światopogląd: zespół poglądów jednostki, będących względnie stałą wizją świata, wyznaczającą postępowanie człowieka względem siebie, innych ludzi i świata przyrody. W światopoglądzie jednostki występują trzy grupy poglądów: 1) dotyczące świata jako całości (jego struktury, powstania, rozwoju i inne); 2) ludzkich spraw egzystencjalnych (sensu ludzkiego życia i jego poszczególnych aspektów, np. szczęścia, cierpienia, śmierci, powinności i inne); 3) ocen i norm moralnych oraz powiązanych z nimi dyrektyw praktycznego działania (ujawniających się w hierarchii wartości, systemie nakazów i zakazów, odpowiedzialności za swoje czyny i inne)". Źródło: T. Hejnicka-Bezwińska, Pedagogika ogólna, s. 511. 
czeń przypisywanych tej kategorii pojęciowej pedagogikę ogólną interesuje głównie dyskurs rozumiany jako ,uwarunkowane historycznie i epistemologicznie reguły budowy wypowiedzi na temat edukacji" ${ }^{19}$. Interesują zatem pedagogikę reguły i zasady, które w określonym czasie historycznym i miejscu (kulturze) legitymizują różne rodzaje wiedzy o edukacji, a więc nie tylko wiedzę pedagogiczną, ale także wiedzę potoczną ludzi i grup społecznych.

W tym miejscu jednak warto jeszcze zwrócić uwagę na jedno zagrożenie wynikające z tego, że jeżeli kiedykolwiek zdarza się nam, że przechodzimy od twierdzeń opisujących świat (zdań empirycznych) do zaleceń, jak ten świat należy urządzić (zdań normatywnych), to jest to sytuacja, w której mamy do czynienia z próbą narzucenia innym naszego systemu wartości.

Sformułowana teza wydaje mi się szczególnie ważna dla pedagogiki jako nauki, więc pozwolę sobie ją rozwinąć, przytaczając fragment książki napisanej wcześniej, ale dzisiaj nie ujęłabym tego inaczej. Oto on:

Pokusa narzucania innym swego systemu wartości jest odwieczną pokusą ludzi, szczególnie ideologów, polityków i administratorów. Z tego powodu edukacja powinna wyposażać ludzi w środki obrony i ochrony przed ideologicznym uwiedzeniem i skutkami manipulacji, wpisującej się w zjawisko szeroko rozumianej „,inżynierii społecznej”. Z drugiej strony chodzi zaś też o to, aby jednostka zachowała otwartość na idee i wartości, nie popadając w stan anomii i alienacji. W ładzie demokratycznym wykorzystywaniu systemu oświatowego do realizowania pokusy ideologicznego uwodzenia na szeroką skalę przeciwdziała społeczny dyskurs o edukacji, respektujący zasady dyskusji racjonalnej, który pozwala na zaistnienie pluralizmu roszczeń edukacyjnych, ale także wymusza ich upublicznione uzasadnianie. W ten sposób tworzy się płaszczyzna społecznych wyborów i odpowiedzialności, stanowiona w społecznym dyskursie o edukacji. Zupełnie czym innym jednak jest realizacja tej pokusy w sytuacji, gdy na szeroką skalę stosuje się środki przemocy, fizycznej, strukturalnej i symbolicznej, jakimi dysponują ustroje totalitarne. W XX wieku mieliśmy do czynienia dwukrotnie z wykorzystaniem nauki do uprawomocnienia ideologii faszystowskiej i komunistycznej, a rezultaty tego określane są mianem wytwarzania „wiedzy zdeprawowanej” (Tyrowicz, 1970).

Pokusa wykorzystania wytworów nauki do uprawomocnienia ideologii znajdowała uzasadnienie w zjawisku, które metodologowie nazywają złudze-

${ }_{19}$ Możemy mówić o trzech znaczeniach przypisywanych kategorii pojęciowej „dyskurs edukacyjny (dyskurs o edukacji)". Patrz: B. Milerski, B. Śliwerski, Leksykon PWN. Pedagogika, Warszawa 2000, s. 50. 
niem naturalistycznym (,błędem naturalizmu”). Dotknęło ono głównie nauki społeczne, ponieważ uczeni chcieli je budować wedle wzorca nauk przyrodniczych, a szczególnie ceniony był przez nich wzorzec uprawiania fizyki. W XX wieku coraz powszechniejsze staje się jednak przekonanie, że pedagogika zorientowana humanistycznie może wytwarzać wszystkie trzy rodzaje wiedzy (empiryczną, hermeneutyczną, emancypacyjną) i prawomocne są różne paradygmaty badań naukowych. Nie znajduje natomiast uzasadnienia i legitymizacji taki dziwny twór nazwany ,,pedagogiką praktyczną”, w ramach którego usytuowano tzw. „naukową pedagogikę socjalistyczną"20.

Ostatnie zdanie nie wyraża negacji „praktyczności pedagogiki”21 (chociaż skłonna byłabym zgodzić się z filozofami, którzy mówią, że najbardziej praktyczna jest teoria), ale wyraża protest przeciwko redukcji pedagogiki po to, aby możliwe stało się instrumentalne jej wykorzystanie do realizacji celów politycznych. Kłopot współczesnej pedagogiki z pedagogiką normatywną (doktrynami pedagogicznymi) polega na tym, że uchylona została wielka narracja podporządkowana realizacji oświeceniowej idei postępu ${ }^{22}$, która uzasadniała redukcję pedagogiki do jednej pedagogii. Można zatem powiedzieć, że pedagogika normatywna, którą wypełniały różnego rodzaju pedagogie (dające się wpisać w określone ideologie edukacyjne), przeżywa kryzys, który może być odczytywany jako kryzys sensu, ponieważ uchylone zostały narracje ten sens konstytuujące. Pytaniem jest: Czy pedagogika potrafi bronić pedagogicznego sensu edukacji, nie będąc zredukowaną do wytwarzania doktryn pedagogicznych jako szczególnej odmiany ideologii edukacyjnych.

Zasygnalizowane kłopoty sprawiły, że pedagodzy na nowo muszą przemyśleć status pedagogiki i jej związek ze społeczną praktyką edukacyjną. W tym miejscu chciałabym posłużyć się opracowaną przez siebie ryciną, która pokazuje związek między różnymi rodzajami wiedzy o edukacji a społeczną praktyką edukacyjną w kontekście przeprowadzonego wcześniej wywodu.

${ }^{20}$ T. Hejnicka-Bezwińska, O zmianach w edukacji. Konteksty, zagrożenia i możliwości, Bydgoszcz 2000, s. 94.

${ }^{21}$ Cudzysłów zastosowany do tej kategorii pojęciowej wskazuje, że może być ona różnie pojmowana. Znaczenie przyjmowane w tym tekście zostanie omówione nieco później.

22 Czołowy filozof francuski uważany za prekursora postmodernizmu - Michel Foucault „upadek wielkich narracji” uważa za najważniejszy aspekt zmiany określanej jako przejście od świata nowoczesnego do świata ponowoczesnego. 
3. Miejsce i status pedagogiki wśród różnych rodzajów wiedzy i związek tej wiedzy ze społeczną praktyką edukacyjną

Model związku między różnymi rodzajami wiedzy o edukacji a społeczną praktyką edukacyjną

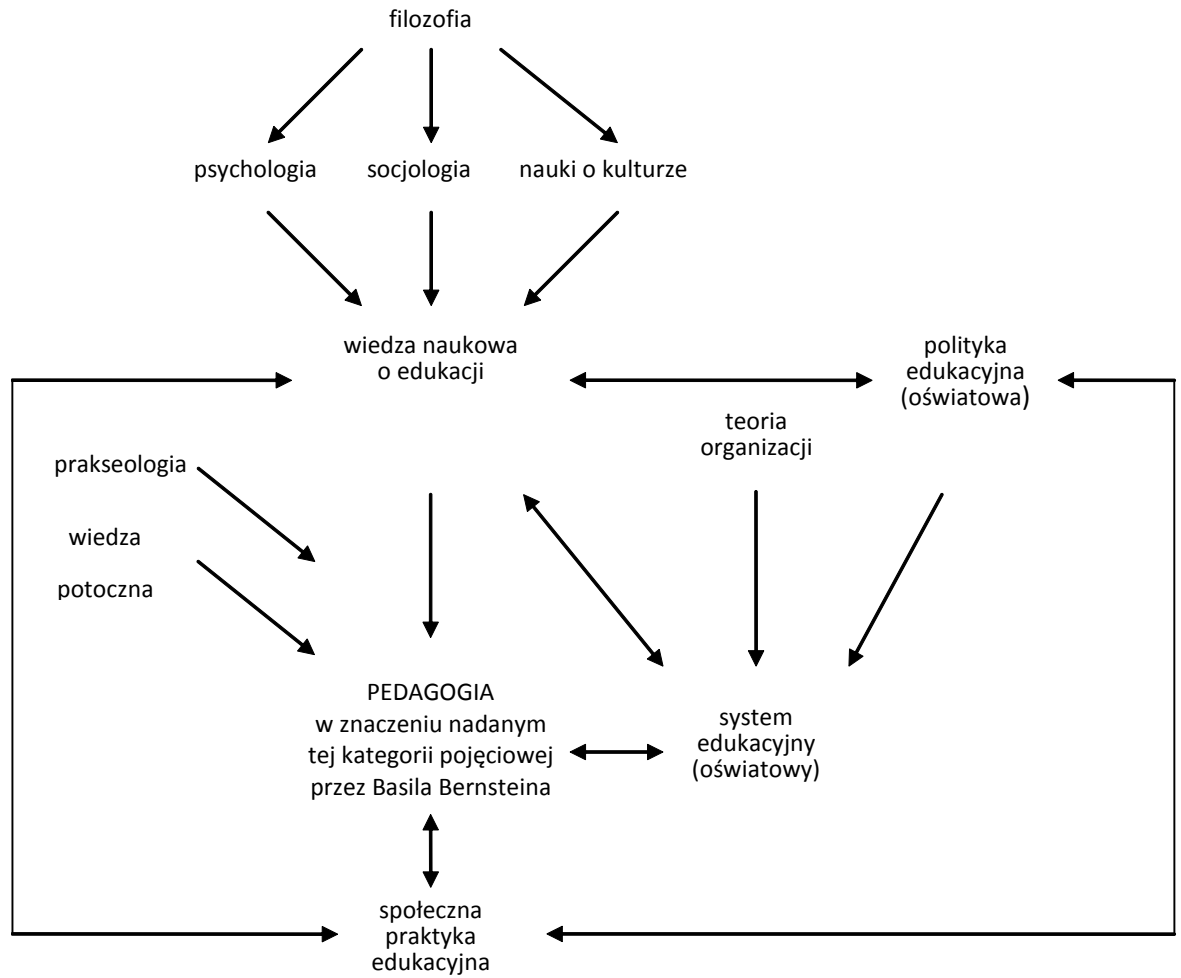

Przyjmujemy, że: „Pedagogia jest stałym procesem, poprzez który jednostka przyswaja sobie nowe formy (lub rozwija dotychczas istniejące formy) postępowania, wiedzy, umiejętności i kryteria ich oceny - od kogoś (lub czegoś), kogo uznaje za stosownego ich dostarczyciela (przekaziciela) i ewaluatora, stosownego tak z punktu widzenia przyswajającego lub innej osoby (instytucji), czy z obydwu naraz"23.

${ }^{23}$ Definicja Basila Bernsteina z pracy Pedagogy, Symbolic Control and Identity: Theory, Research, Crtique, Lanham 2001 została przetłumaczona przez Zbigniewa Kwiecińskiego 
Przedstawiony model związku między różnymi rodzajami wiedzy o edukacji a społeczną praktyką edukacyjną znajduje też uzasadnienie w innej wypowiedzi Zbigniewa Kwiecińskiego inspirowanej tekstami Basila Bernsteina. Oto stosowny cytat:

Podejmuję tu kwestię: co właściwie jest nośnikiem trwałych i powtarzalnych wzorów kształcenia, wychowania i oświaty jako podsystemu społecznego? Na pewno nie jest nim naukowa pedagogika akademicka [...]. Moim zdaniem nie jest ona owym przenośnikiem trwałości wzorów edukacyjnych nie tylko dlatego, że jest oderwana od rzeczywistości, jest nieprzekładalna na zadania oświatowe, kształceniowe i wychowawcze, ale dlatego bardziej jeszcze, że pedagogika naukowa wcale nie leży w glównym nurcie refleksji nad edukacją. Pisarstwo i „badania” edukacyjne są zdominowane przez twory dalekie od spełniania standardów naukowych, a pedagogiczne instytucje akademickie są przepełnione przez chętnie piszących „refleksyjnych praktyków”. Co zatem jest w jej centrum, w głównym nurcie? Jeśli tego głównego myślenia i pisania o edukacji nie stanowi pedagogika naukowa, to może nią być pedagogia, czyli względnie spójny i trwały zbiór praktyk edukacyjnych, które są możliwe do zrekonstruowania przez „refleksyjnych praktyków”, uczestników tych praktyk, chętnych do mówienia i pisania o nich, formułowania algorytmów stałych zachowań i drobnych w nich innowacji, nienaruszających ich istoty ${ }^{24}$.

Ze swojej strony chciałabym tylko wyrazić przekonanie, że wprowadzenie do współczesnej pedagogiki zapoznanej wcześniej kategorii pojęciowej „,pedagogii” w znacznym stopniu umożliwiło jasne opisanie zmian dokonujących się w relacjach łączących różne rodzaje wiedzy ze społeczną praktyką edukacyjną.

Odwołując się do przedstawionego modelu, chciałabym tylko jeszcze wythumaczyć brak w tym modelu pedagogiki jako dyscypliny naukowej. Powodem tego braku jest niemożność jednoznacznego jej usytuowania. Można by ją bowiem umieścić obok psychologii, socjologii i nauk o kulturze. Mogłaby też być jedną z nauk o kulturze, ale mogłaby też być tą dyscypliną naukową, która wykorzystując dorobek wszystkich dyscyplin naukowych „filtruje” społeczną praktykę edukacyjną przez pryzmat różnych teorii na-

i wykorzystana w artykule: Z. Kwieciński, ,Niewidzialna pedagogia”. Tryby nabywania wiedzy i tożsamości wedlug późnego Basila Bernsteina - wprowadzenie do dyskusji, w: T. Bauman (red.), Uczenie się jako przedsięwzięcie na całe życie, Kraków 2005, s. 63.

${ }^{24}$ Z. Kwieciński, Pedagogie przekorne wobec pedagogii głównych nurtów. Problem, model, zachęta do dyskusji, w: T. Hejnicka-Bezwińska, R. Leppert (red.), Ewolucja „ogólności”" $w$ dyskursach pedagogicznych, Bydgoszcz 2005, s. 67-68. 
ukowych. Fakt braku pedagogiki w amerykańskim systemie nauk oraz ujawniane zagrożenie ,końcem pedagogiki” powstrzymuje mnie przed ostatecznym wpisaniem pedagogiki w określone miejsce tego modelu.

Przedstawiony model związku różnych rodzajów wiedzy o edukacji ze społeczną praktyką edukacyjną uzasadnia jednak odejście od pedagogiki jako dyscypliny naukowej zredukowanej do wytwarzania skutecznych doktryn pedagogicznych, uzasadnia też wprowadzenie do pedagogiki problematyki ideologicznego uwikłania celów formułowanych w obszarze edukacji. Zawiera też zobowiązanie do ujawniania owej ideologiczności. Ten ostatni problem chciałabym objąć namysłem w ostatniej części niniejszego tekstu, pytając o stopień wypełnienia tego zobowiązania przez depozytariuszy kapitału pedagogiki w sytuacji, w której dwa ostatnie kryzysy tej dyscypliny naukowej wywołane zostały czynnikami niewpisującymi się w logikę rozwoju dyscypliny naukowej.

\section{Zakres i poziom zainteresowania pedagogów ideologiami edukacyjnymi w Polsce}

Transformacja ustrojowa stworzyła szanse na włączenie w zakres ważnych zainteresowań pedagogów problematyki ideologii edukacyjnych. Najpierw były to informacje o tekstach i dyskursach obecnych od dziesięcioleci na Zachodzie. Upowszechnieniu tej wiedzy dobrze służyła seria wydawana pod wspólnym tytułem Nieobecne dyskursy. Redaktorem kolejnych tomów był Zbigniew Kwieciński, a wydawcą Uniwersytet Mikołaja Kopernika w Toruniu. Ważną rolę odegrały także tłumaczenia, między innymi wspomniany wcześniej podręcznik socjologii Meighana i praca Gutka. Podjęte zostały też próby rekonstrukcji ideologii najważniejszych dla praktyki edukacyjnej. Wspomnę o dwóch pracach ${ }^{25}$, których autorzy podjęli próbę rekonstrukcji następujących ideologii edukacyjnych: „romantycznej”, „transmisji kulturowej”, ,progresywnej”. Dzisiaj skłonna byłabym uznać za najważniejsze ideologie edukacyjne: ideologię konserwatywną, ideologię liberalną, ideologię socjalizmu (utopijnego „komunitariańskiego”) ${ }^{26}$. Te trzy ideologie zdomino-

${ }^{25}$ T. Hejnicka-Bezwińska, W poszukiwaniu tożsamości pedagogiki. Świadomość teoretyczno-metodologiczna współczesnej pedagogiki polskiej (geneza i stan), Bydgoszcz 1989; B. Śliwerski, Współczesne teorie i nurty wychowania, Kraków 1998. Obie te rekonstrukcje oparte były na pracy: L. Kolberg, R. Mayer, Rozwój jako cel wychowania. Materiały do użytku konwersatorium „Edukacja wobec przemian”, Torun 1990.

${ }^{26}$ Uzasadniam i opisuję to w: T. Hejnicka-Bezwińska, Pedagogika ogólna, rozdział 8.3., s. 392-407. 
wały myślenie ludzi w XIX i XX wieku. Łączyło te ideologie pragnienie i obietnica, że projekt zrealizowania określonej wizji świata (w każdej ideologii inny) możliwy jest poprzez włączenie do tej zmiany instytucji szkoły, a dokładniej całego sytemu oświatowego, a nawet sytemu edukacyjnego. Innym jednak celom i przy zastosowaniu innych środków edukacyjnych miała zostać zrealizowana ideologiczna wizja świata w każdym z wymienionych projektów uczynienia świata lepszym.

Z charakterystyki ideologii edukacyjnych (niezależnie od tego, jaką typologię zastosujemy) wynika, że ideologie są bezpośrednio związane z dzialaniem w obszarze edukacji.

W ostatnim dwudziestoleciu mamy do czynienia wyraźnie ze wzrostem zainteresowania ideologiami, które faktycznie mają znaczenie, to znaczy mają wpływ na działania i zmiany dokonujące się w społecznej praktyce edukacyjnej. Największe zainteresowanie w Polsce po roku 1989 budzą ideologie liberalne, a najbardziej znaczące prace z tego zakresu powstały w środowisku pedagogów Uniwersytetu Adama Mickiewicza w Poznaniu (Eugenia Potulicka, Zbyszko Melosik) oraz Uniwersytetu Gdańskiego (Joanna Rutkowiak, Tomasz Szkudlarek, Ewa Zalewska, Małgorzata LewartowskaZychowicz). Mniejsze - powiedziałabym nawet marginalne - zainteresowanie budzi ideologia konserwatywna i ideologia socjalizmu. Prace dotyczące ideologii edukacyjnych najczęściej usytuowane są w nurcie „pedagogiki krytycznej”. Odnotować w sposób szczególny chciałabym pojawienie się prac, w których wiedza o ideologiach edukacyjnych została wykorzystana w badaniach empirycznych. Wśród tych prac przykładem może być praca Ewy Zalewskiej, zatytułowana Ideologiczne konteksty działalności zawodowej nauczycieli w okresie transformacji ustrojowej w Polsce, wydana w 2000 roku przez wydawnictwo UG.

Pisząc na temat ideologicznych uwikłań celów edukacyjnych, trudno też pominąć inicjatywę zorganizowania konferencji na temat: Ideologia w edukacji-edukacja w ideologii. Pytania o wspótczesność. Inicjatywa ta podjęta została przez Dolnośląską Szkołę Wyższą i UMK. Obrady otwierała dyskusja panelowa zrealizowana przez przedstawicieli różnych dyscyplin naukowych na temat: Ideologia, zaangażowanie, działanie, pytanie o edukację. Zapowiadana publikacja pokaże, że problem ideologii edukacyjnych wymaga interdyscyplinarności i uwzględnienia w debacie różnych poziomów ogólności.

Literatura dotycząca ideologii oraz udział w wymienionej konferencji uświadomiły mi jednak pewien paradoks, ważny w przezwyciężaniu rozbieżności między tym, co stanowi kapitał wiedzy naukowej, a tym, co wiedzą i myślą podmioty edukacji w kulturze ładu demokratycznego opartego na 
gospodarce rynkowej. Nauka dostarcza nam wielu uzasadnień, że społeczna praktyka (także w dziedzinie edukacji) nie jest aideologiczna. W praktyce edukacyjnej dominującym nastawieniem - wyrażanym także werbalnie jest programowo wyrażana aideologiczność i apolityczność (naiwnie i w dobrej wierze). Łatwe jest wskazanie przyczyn tego szczególnego „uczulenia” podmiotów edukacji, uczestniczących w społecznej praktyce edukacyjnej bezpośrednio oraz w dyskursie o zmianach w obszarze edukacji. Można by tym nie przejmować się, gdyby skutkiem tego nie było powiększanie się rozbieżności między ofertą dotyczącą wiedzy, formułowaną przez pedagogikę jako dyscyplinę naukową a oczekiwaniami jej potencjalnych odbiorców jako podmiotów edukacji ${ }^{27}$.

Świadomość tego skłania mnie do wykorzystania następnej części artykułu do tego, aby możliwie najprecyzyjniej przedstawić swój namysł nad ideologicznym uwikłaniem celów edukacyjnych, dokonując jednocześnie swoistego podsumowania.

\section{Podsumowanie}

Wiedza naukowa (a tym bardziej wiedza pedagogiczna) nie jest jedynym rodzajem wiedzy, która jest wykorzystywana w społecznej praktyce edukacyjnej. Pedagogika współczesna upatruje więc rację swego istnienia w wytwarzaniu wiedzy - możliwie najlepiej legitymizowanej - o tej dziedzinie kultury, którą nazywa się kategorią pojęciową edukacji. Kilka stron, poprzedzających model związków różnych rodzajów wiedzy o edukacji ze społeczną praktyką edukacyjną, poświęconych w zasadzie zostało przekonywaniu odbiorców tekstu do tezy, że cele formułowane i realizowane w społecznej praktyce edukacyjnej są i muszą być ideologicznie uwikłane, ponieważ nauka nie może ludziom powiedzieć, a grupom społecznym narzucić i skutecznie wyegzekwować tego, co czynić mają. Nauki humanistyczne wypracowały jednak metodologię ujawniania, opisywania, wyjaśniania i interpretowania określonych praktyk społecznych, dzięki której możemy otrzymać wiedzę o najwyższym poziomie wiarygodności, dającej się weryfikować w społecznym dyskursie o różnych kwestiach, w tym również o szczegółowych kwestiach związanych z edukacją. Wszelkie ideologie ujawniają się więc wtedy, kiedy przedmiotem badań uczynimy określony fragment rzeczywistości. Wspomniany już wcześniej Meighan wymienia jako obiekty badań nad ideologiami edukacyjnymi: formułowane cele i całe projekty edukacyjne, mo-

27 Tę tezę uzasadniłam w artykule: T. Hejnicka-Bezwińska, Rekonstrukcja. 
dele ról (ucznia, nauczyciela), kody kulturowe i wiedzę uczniów, programy nauczania, strukturę i organizację systemu oświatowego, organizację przestrzeni, wykorzystanie czasu przez ucznia, nauczyciela i w szkole, sposób użycia języka i inne.

Przyjmując powyższe założenia, skłonna jestem bronić modelu przedstawionego w części trzeciej niniejszego artykułu.

Mam świadomość, że na ogół niechętnie przez czytelników przyjmowane są analizy kategorii pojęciowych. Jednak w sytuacji, kiedy piszący wie, że są to kategorie wieloznaczne i różnie definiowane, co jest szczególną właściwością języka w warunkach dokonujących się zmian, mających charakter zmian traumatogennych, to zobowiązaniem piszącego jest zapobieganie różnego rodzaju deformacjom komunikacyjnym i poznawczym. Jednym ze środków zapobiegających temu są analizy językowe.

Coraz częściej w pracach pedagogów stosowana jest kategoria pojęciowa pedagogii dla nazwania takich wytworów jak doktryny pedagogiczne, ideologie wychowania, ukryte programy wychowania i inne, a w ostatnim czasie mamy do czynienia z upowszechnianiem się tej kategorii w znaczeniu nadanym przez Basila Bernsteina. Jeżeli przyjmiemy to ostatnie znaczenie, to obiektem badań pedagogicznych mogą stać się pedagogie rozumiane jako względnie spójne i trwałe zbiory praktyk edukacyjnych, służących realizacji zwerbalizowanych lub ukrytych celów edukacyjnych. Wyniki badań, przedstawione $\mathrm{w}$ raportach $\mathrm{z}$ badań nad najogólniej pojmowanymi efektami edukacji ${ }^{28}$, dostarczać mogą ważnych przesłanek podmiotom społecznego dyskursu o edukacji. Badanie z kolei dyskursów o edukacji (na poziomie tekstów, interpretacji i kontekstów) pozwala na ujawnianie założeń i ideologii je konstytuujących.

Tworzenie najbardziej wiarygodnej wiedzy o społecznej praktyce edukacyjnej może być zadaniem sprzyjającym trosce o ,pedagogiczny sens edukacji”. Kategoria „pedagogicznego sensu edukacji” jest kategorią dopiero próbującą znaleźć swoje miejsce w pedagogice współczesnej. Taką próbą jej zdefiniowania oraz wskazania kontekstu i możliwych zastosowań pozwolę sobie niniejszy tekst zakończyć.

Pedagogiczny sens edukacji (pedagogiczny sens społecznej praktyki oświatowej): Popularyzacja hasła „uczyć się, aby być” oraz jego akceptacja - a nawet afirmacja - sprawiły, że inaczej zaczął być odczytywany „pedagogiczny

${ }^{28}$ Takimi raportami są np. raporty PISA, raporty Janusza Czapińskiego dotyczące jakości życia Polaków, ostatni raport o stanie edukacji: (Michał Fedorowicz (red.), Spoleczeństwo $w$ drodze do wiedzy. Raport o stanie edukacji 2010, Warszawa 2011). Zapowiadamy jest też raport o wykorzystaniu czasu przez nauczycieli. 
sens edukacji”. Stało się to impulsem dla upowszechniania się innego myślenia o edukacji, systemie oświatowym i szkole. Międzynarodowa Komisja do spraw Edukacji dla XXI wieku potwierdziła tę fundamentalną zasadę, że edukacja powinna przyczyniać się do pełnego rozwoju każdej jednostki. Rozwój z kolei trwa przez całe życie, jest procesem dialektycznym, rozpoczynającym się poznaniem siebie samego, aby następnie otworzyć się na relacje z bliźnimi. W tym ujęciu edukacja jest przede wszystkim wewnętrzną i indywidualną wędrówką człowieka przez kolejne etapy kształtowania się jego osobowości. Zakładając skuteczne działanie profesjonalne, edukacja jako czynnik tego pełnego rozwoju jest procesem jednocześnie indywidualnym i interaktywną strukturą społeczną, ale szkoła jako instytucja może stwarzać lepsze lub gorsze warunki do wywierania politycznego (zamierzonego i społecznie uzgodnionego) wpływu na procesy socjalizacji dorastającego pokolenia. Zamierzenia edukacyjne faktycznie realizowane wymagają ciągłej interpretacji, a naczelne cele kształcenia i wychowania (np. osiągnięcie przez ucznia dojrzałości) świadomie formułowane być powinny jako cele otwarte i nie dające się zoperacjonalizować. Wewnątrz ram, które są dane przez instytucje, nauczyciele mają prawo do ustalania swoich priorytetów, poszukiwania własnej metodyki. Zdaniem K.J. Tillmanna, biurokratyczna organizacja systemu oświatowego napotyka jednak granice wynikające z pedagogicznego sensu szkoły, do którego poszukiwania i obrony jest nauczycielom potrzebne wykształcenie pedagogiczne ${ }^{29}$.

Pytaniem pozostaje: Czy pedagogika współczesna i kształcenie akademickie w zakresie pedagogiki wyposaża podmioty edukacji w taką wiedzę, umiejętności i kompetencje, które pozwalają im aktywnie i skutecznie uczestniczyć w obronie pedagogicznego sensu edukacji?

\section{The Ideological Implication of Objectives Formulated within the Area of Education (Summary)}

The politicization of the process of introducing pedagogics as a scientific discipline into university structures at the turn of the $18^{\text {th }}$ and $19^{\text {th }}$ centuries, made it particularly prone to being exploited. The current cultural changes, including the changes taking place in science and social educational practices, enable overcoming this disadvantageous implication.

29 T. Hejnicka-Bezwińska, Pedagogika ogólna, s. 494. 
The model of relationship between various types of knowledge about education and social educational practices which is presented in this article, demonstrates that there is no direct relationchip between scientific knowledge about education and social educational practices. One can say that contemporary pedagogics does not form educational practices, but researches it and reveals through the research process the ideological implications of objectives formulated and achieved within the area of education. Hence, it provides the subjects of social discourse about education with well verified premises. 